\title{
Activating point mutations in cyclin-dependent kinase 4 are not seen in sporadic pituitary adenomas, insulinomas or Leydig cell tumours
}

\author{
V V Vax ${ }^{1,5}$, R Bibi $^{1}$, S Diaz-Cano ${ }^{2}$, M Gueorguiev ${ }^{1}$, B Kola ${ }^{1}$, \\ N Borboli ${ }^{1}$, B Bressac-de Paillerets ${ }^{3}$, G J Walker ${ }^{4}$, I I Dedov ${ }^{5}$, \\ A B Grossman ${ }^{1}$ and $\mathbf{M}$ Korbonits ${ }^{1}$ \\ ${ }^{1}$ Department of Endocrinology, St Bartholomew's Hospital, London EC1A 7BE, UK \\ ${ }^{2}$ Department of Histopathology, St Bartholomew's Hospital, London EC1A 7BE, UK \\ ${ }^{3}$ Service de Génétique, Institut Gustave Roussy, 94805 Villejuif Cedex, France \\ ${ }^{4}$ Human Genetics Laboratory, Queensland Institute of Medical Research, Brisbane 4029, Australia \\ ${ }^{5}$ Department of Neuroendocrinology, Russian Center of Endocrinology, Moscow 107036, Russia \\ (Requests for offprints should be addressed to M Korbonits, Department of Endocrinology, Endocrine Oncology, St Bartholomew's Hospital, \\ 59 Bartholomew Close, Unit 1·1, London EC1A 7BE, UK; Email: m.korbonits@qmul.ac.uk) \\ ( $\vee \vee V a x$ and R Bibi contributed equally to this work)
}

\begin{abstract}
Cell cycle dysregulation is one of the defining features of cancer. Cyclin-dependent kinase 4 (CDK4), together with its regulatory subunit cyclin $\mathrm{D}$, governs cell cycle progression through the G1 phase. Cyclin-dependent kinase inhibitors, including $\mathrm{p} 16^{\mathrm{INK} 4 \mathrm{~A}}$ (encoded by CDKN2A), in turn regulate CDK4. In particular, dysregulation of the $\mathrm{p} 16 / \mathrm{CDK} 4 /$ cyclin D complex has been established in a variety of types of human tumours. Dominant activating mutations affecting codon 24 of the CDK4 gene (replacement of Arg24 by Cys or His) render CDK4 insensitive to $\mathrm{p} 16^{\mathrm{INK} 4}$ inhibition and are responsible for melanoma susceptibility in some kindreds. However, 'knock-in' mice homozygous for the CDK4 ${ }^{\mathrm{R} 24 \mathrm{C}}$ mutation were noted to develop multiple neoplasia, most commonly including endocrine tumours: pituitary adenomas, insulinomas and Leydig cell testicular tumours. We therefore speculated that sporadic human endocrine tumours might also harbour such mutations. The aim of the current study was to analyze the CDK4 gene for the two characterized activating mutations, R24C and R24H, in sporadic human pituitary adenomas, insulinomas and
\end{abstract}

Leydig cell tumours. We used DNA extracted from 61 pituitary adenomas, and paired tumorous and neighboring normal genomic DNA extracted from 14 insulinoma and 6 Leydig cell tumour samples. Genomic DNA from patients with familial melanoma harbouring the R24C or the $\mathrm{R} 24 \mathrm{H}$ mutations served as positive controls. All samples were subjected to PCR, mutation-specific restriction digests and/or sequencing. Both methodologies failed to detect mutations at these two sites in any of the sporadic endocrine tumours including pituitary adenomas, benign or malignant insulinomas or Leydig cell tumours, while the positive controls showed the expected heterozygote patterns. Protein expression of CDK4 was demonstrated by immunohistochemistry and Western blotting in pituitary and pancreatic samples. These data suggest that the changes in the regulatory 'hot-spot' on the CDK4 gene, causing various endocrine tumours in $\mathrm{CDK} 4^{\mathrm{R} 24 \mathrm{C} / \mathrm{R} 24 \mathrm{C}}$ mice, are not a major factor in sporadic pituitary, insulin $\beta$-cell or Leydig cell tumorigenesis.

Journal of Endocrinology (2003) 178, 301-310

\section{Introduction}

Abnormalities in cell cycle stimulators and inhibitors are increasingly recognized as crucial factors in tumorigenesis. Examples of cell cycle stimulators include the cyclins and cyclin-dependent kinases (CDKs), whilst examples of inhibitors of the cell cycle include the retinoblastoma protein $(\mathrm{Rb})$ and the CDK inhibitors (INK4 and Cip/Kip group; Fig. 1) (Pavletich 1999). In G1 phase, various mitogenic signals activate the cell cycle via the cyclin $\mathrm{D} / \mathrm{CDK} 4$ complex which, in turn, can be inhibited by the CDK inhibitor $\mathrm{p} 16^{\text {INK4a }}$ (p16, encoded by CDKN2A) via binding to CDK4. Mutation in the CDK4 gene was first described in melanoma cells (Wölfel et al. 1995): the mutation involved an arginine to cysteine change (Arg $\rightarrow$ Cys) at codon 24 (R24C) as a result of a single nucleotide change (CGT to TGT). This mutation is an activating mutation, as it results in growth advantages 


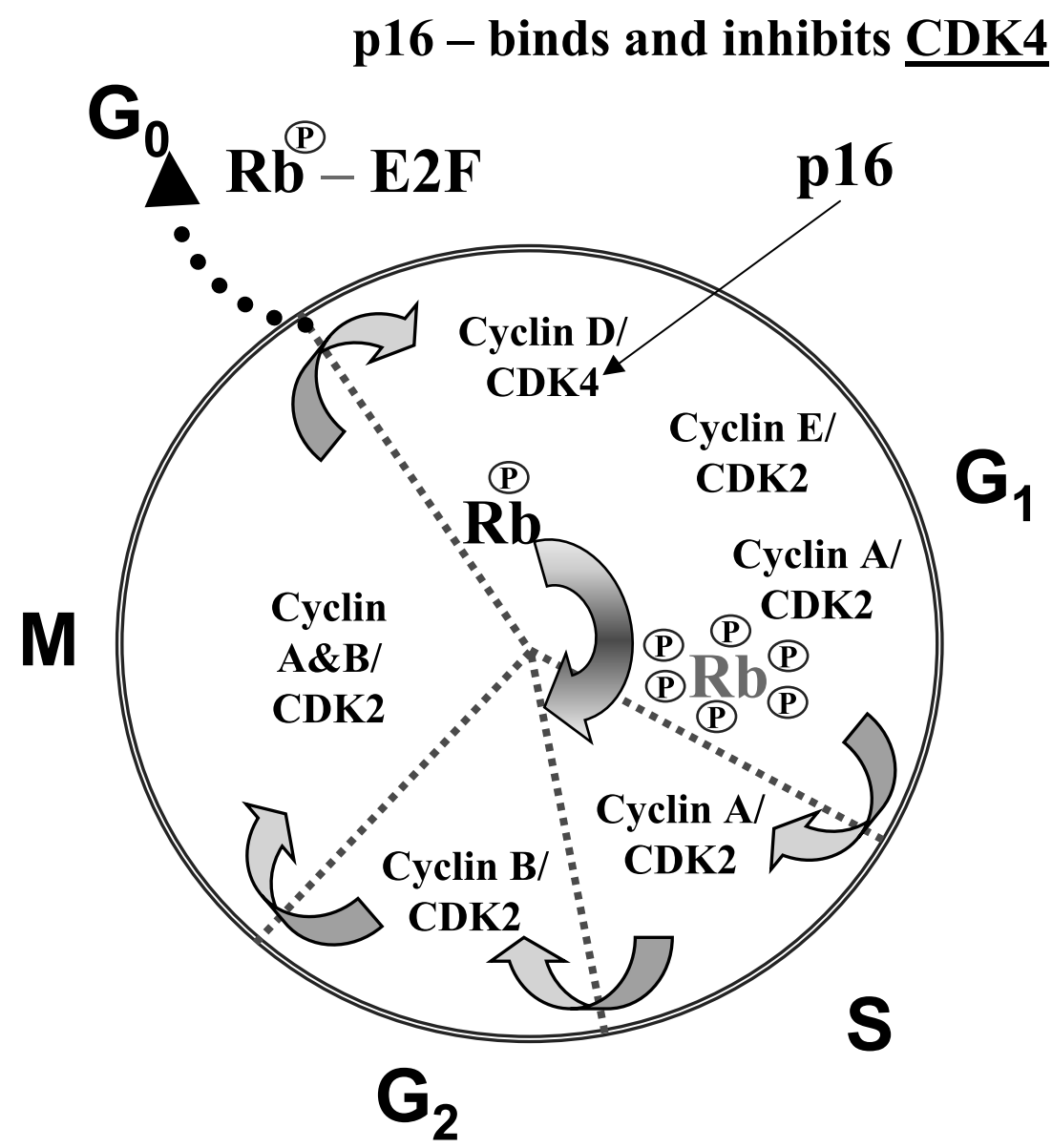

Figure 1 Cell cycle stimulators and inhibitors. Rb is a tumour suppressor protein which controls the G1-S transition partly by blocking the activity of a group of transcription factors, E2F (Zhang et al. 1999, Malumbres \& Barbacid 2001). Progressive phosphorylation of $\mathrm{Rb}$ caused by the various cyclin/CDK complexes results in the release of the E2F complex, therefore enabling DNA synthesis to occur. The CDK inhibitor, p16, acts specifically by binding and inhibiting the cyclin D/CDK4 complex.

because it prevents p16 binding, while maintaining the ability of CDK4 to form a functional kinase with cyclin D. It was previously known that $\sim 20 \%$ (range $<5 \%$ to $>50 \%$ in individual studies) of familial melanoma kindreds harbour a mutation in p16, but germline CDK4 mutations have also been identified in three familial melanoma cases (Kefford et al. 2002). Zuo et al. (1996) examined 31 melanoma families with no p16 mutations, two of which harboured a heterozygote R24C mutation. A second germline mutation was described by Soufir et al. (1998) in one of 48 French melanoma families. The striking point about this second mutation is that it occurs in the same Arg24 codon as the previously mentioned R24C mutation, directly involved in binding to p16 proteins, but in this case arginine is exchanged for histidine (Arg $\rightarrow$ His) as a consequence of a single nucleotide change $(\mathrm{CGT} \rightarrow \mathrm{CAT})$. To test its in vivo relevance, the CDK4 R24C allele was 'knocked in' to the germline of mice, using homologous recombination (Rane et al. 1999, Sotillo et al. 2001). Whilst expression of this mutant gene did not cause any gross developmental defects, the mice were noticed to be on average 5-20\% larger than their wildtype controls. Spontaneous melanoma was not observed in these mice, but following treatment with two carcinogenic compounds, 7,12 dimethylbenz[a]anthracene (DMBA) and 12-0-tetradecanoylphorbol-13-acetate (TPA), they developed large papillomas that frequently progressed to invasive skin carcinomas. Interestingly, CDK4 $4^{\mathrm{R} 24 \mathrm{C} / \mathrm{R} 24 \mathrm{C}}$ mice developed a wide spectrum of tumours with a $55 \%$ incidence of endocrine neoplasia, specifically 3 types of endocrine tumours: those of Leydig cell origin were the most frequent $(62 \%$ prevalence), followed by pancreatic $\beta$-islet cells (31\%) and pituitary cells $(22 \%)$. Pituitary tumours expressed a variety of hormones and were of adenohypophyseal origin (80\%). This is in contrast to $\mathrm{pRb}, \mathrm{p} 27$ or $\mathrm{p} 18^{\mathrm{INK} 4 \mathrm{c}}$ knockout mice: these animals also 
commonly develop pituitary tumours, which mostly originated from the adrenocorticotrophin (ACTH)-secreting pars intermedia.

CDK4 knockout animals have also been generated $\left(\mathrm{CDK} 4^{-{ }^{-}}\right)$(Rane et al. 1999). Both male and female mice lacking the CDK4 protein were $50 \%$ smaller than wild-type animals, and were sterile, with reduced numbers of Leydig cells and abnormal corpus luteum formation. CDK4 ${ }^{-1-}$ mice also showed features of diabetes mellitus: histology of the pancreatic tissue revealed severe deformity and a reduction in the size of the islet cells, principally the $\beta$ islet cells. These results indicate that CDK4 is required for postnatal proliferation of $\beta$ islet cells, as both the $\mathrm{CDK} 4^{+/ \mathrm{R} 24 \mathrm{C}}$ and $\mathrm{CDK} 4^{\mathrm{R} 24 \mathrm{C} / \mathrm{R} 24 \mathrm{C}}$ mice develop $\beta$ cell tumours while the $\mathrm{CDK} 4^{-/-}$knockout types were born with normal islet cell number and morphology but develop diabetes soon after.

Based on the above findings, we investigated the possible presence of these two activating mutations of CDK4 in sporadic human pituitary adenomas, insulinomas and Leydig cell tumours.

\section{Materials and Methods}

\section{Tumour specimens}

Pituitary samples Human pituitary adenomas were obtained at the time of transsphenoidal surgery and were stored at $-80{ }^{\circ} \mathrm{C}$. All studies were approved by the local Ethics Committee. The tumour type was determined on the basis of clinical and biochemical findings before surgery, and histological and immunocytochemical analysis of the removed tissue sample. Tumour extension was determined directly at surgery as well as by pre-operative magnetic resonance imaging (MRI). We investigated 61 pituitary tumours (46 cDNA and 15 genomic DNA samples). Of these, 17 were classified as active somatotroph adenomas (10 somatotroph, 5 somatomammotroph and 2 sparsely-granulated somatotroph), 36 were clinically nonfunctioning pituitary adenomas (cNFPA, 29 null cell adenomas, 2 silent corticotrophs, 4 silent gonadotrophs and 1 oncocytoma), 5 were corticotroph adenomas, 3 were active lactotroph adenomas; 35 of the pituitary tumours $(57 \cdot 4 \%)$ had invasive extension. The clinico-pathological details of the patients are included in Table 1. For the immunoblotting studies autopsy samples were used as normal pituitaries.

Insulinoma samples Genomic DNA from 14 insulinomas was extracted from formalin-fixed, paraffinembedded tissue. Eight of these patients had isolated tumours (one of them was an islet cell carcinoma), whilst 5 of the patients had insulinomas as part of multiple endocrine neoplasia type 1 (MEN1) syndrome. One of the samples analysed was that of a metastatic lesion from the liver of a patient with an insulinoma. In all cases, both tumorous tissue and normal tissue surrounding the tumour were analysed. The data of the patients with insulinomas are included in Table 2.

Leydig cell tumour samples Six cases of Leydig cell tumours were investigated. In all cases, both tumorous tissue and normal testis tissue surrounding the tumour were analysed from microdissected samples. The data of patients with Leydig cell tumours are included in Table 3.

\section{Nucleic acid extraction}

Total RNA prepared from fresh-frozen pituitary tumours was transcribed to cDNA as previously described (Korbonits et al. 2001). Genomic DNA from tissue of pituitary adenomas was extracted using the QIAamp DNA Mini Kit (Qiagen). Microdissected sections from formalin-fixed, paraffin-embedded samples were taken from 10- $\mu \mathrm{m}$ unstained sections of insulinomas, Leydig cell tumours and histologically normal pancreatic and testis tissue. The DNA extraction was performed as follows (Diaz-Cano \& Brady 1997): $10 \mathrm{ml}$ volume lysis buffer was made, consisting of $200 \mu \mathrm{l}$ proteinase $\mathrm{K}(200 \mu \mathrm{g} / \mathrm{ml})$, $500 \mu \mathrm{l}$ Tris $\mathrm{pH} 8.3(50 \mathrm{mM}), 50 \mu \mathrm{l}$ carrier glycogen $(100 \mu \mathrm{g} / \mathrm{ml}), 100 \mu \mathrm{l}$ Tween 20 (0.5\%), $150 \mu \mathrm{l}$ calcium chloride $(1.5 \mathrm{mM})$ and finally $9000 \mu \mathrm{l}$ sterile water. A portion $(300 \mu \mathrm{l})$ of this lysis buffer was added to each microcentrifuge tube with the tissue fragments. The samples were kept at $61{ }^{\circ} \mathrm{C}$ for three days while an additional $6 \mu \mathrm{l}$ proteinase $\mathrm{K}$ were added to each tube every $12 \mathrm{~h}$. At the end of the third day, one drop of Chelex beads and, after $5 \mathrm{~min}, 2 \mu \mathrm{l} 0.5 \mathrm{M}$ EDTA were added to each tube. Samples were precipitated with ice-cold absolute ethanol in the presence of $0.3 \mathrm{M}$ sodium acetate, $\mathrm{pH} 5 \cdot 2$. All samples were then dissolved in $15 \mu \mathrm{TE}$ buffer, $\mathrm{pH}$ $8 \cdot 0$, and stored in the $-20{ }^{\circ} \mathrm{C}$ freezer until further use.

Positive controls were genomic DNA (gDNA) samples extracted from blood from patients with familial melanoma syndrome due to CDK activating mutations (Zuo et al. 1996, Soufir et al. 1998).

\section{Primers and $P C R$ reaction}

The samples were subjected to PCR amplification of codon 24 area (codon 1-41) of the CDK4 gene using genomic primers (sense 5'GCTGCAGGCTCATACCAT CCT3' and antisense 5'CTCTCACACTCTTGAGG GCC3', product size $198 \mathrm{bp}$ ) for the insulinomas, Leydig cell tumours and for the gDNA extracted from the 15 pituitary adenomas. We used intron-skipping cDNA primers (sense 5'GTGTATGGGGCCGTAGGAAC3' and antisense 5'CCATTGGGGACTCTCACACT3', product size $219 \mathrm{bp}$ ) for the pituitary cDNA samples extracted from fresh-frozen pituitary adenomas. Each PCR reaction was run with a no template control. For a $25 \mu \mathrm{l}$ reaction we used $1 \mu \mathrm{l}$ gDNA or $2.5 \mu \mathrm{l}$ cDNA 
Table 1 Characteristics of patients with pituitary tumours

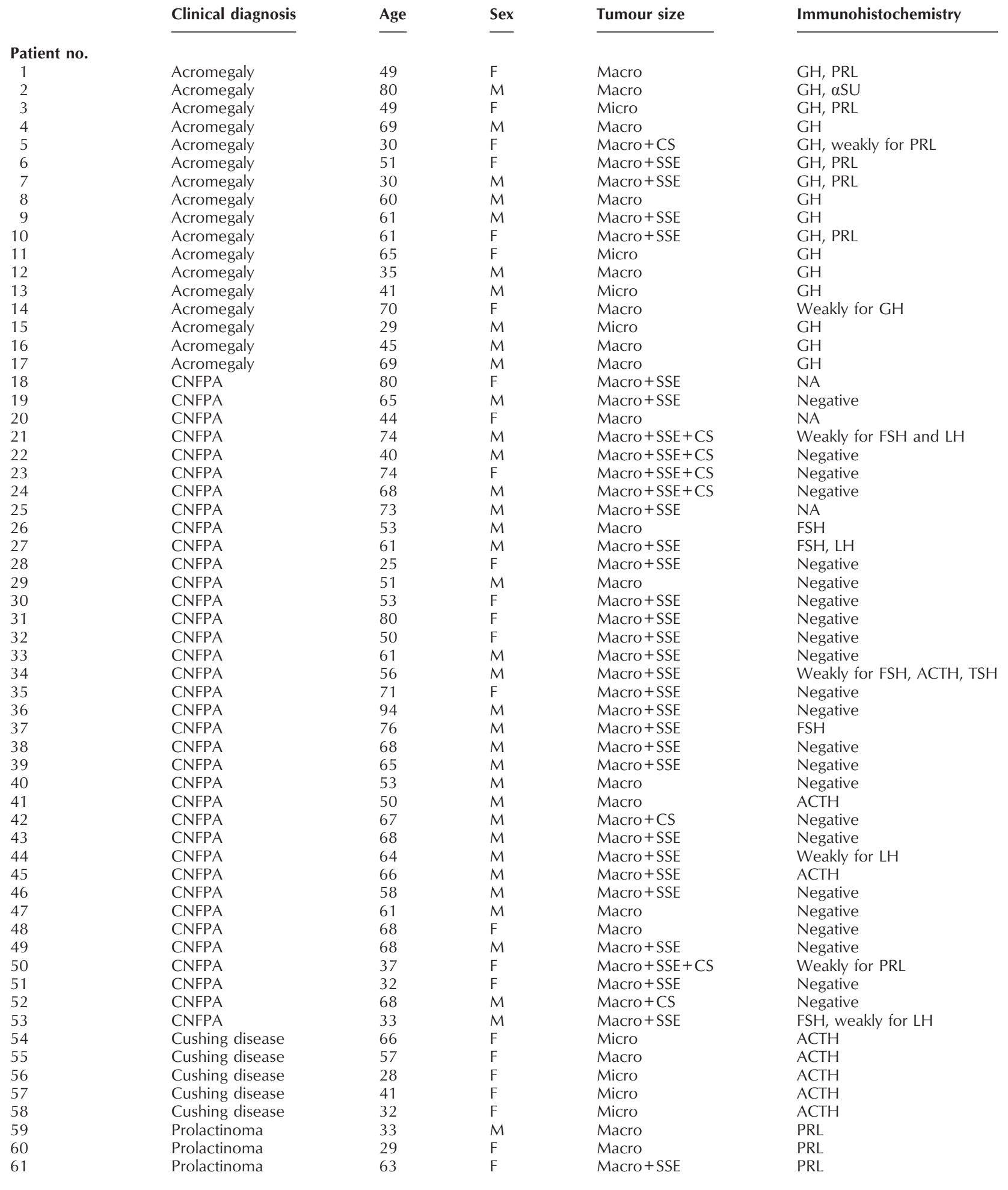

NA, not available; CNFPA, clinically non-functioning pituitary adenoma; macro, macroadenoma; micro, microadenoma; SSE, suprasellar extension; $\mathrm{CS}$, cavernous sinus extension; $\mathrm{GH}$, growth hormone; PRL, prolactin; $\alpha \mathrm{SU}, \alpha$-subunit; $\mathrm{FSH}$, follicle-stimulating hormone; $\mathrm{LH}$, luteinising hormone; TSH, thyroid-stimulating hormone; ACTH, adrenocorticotrophin. 
Table 2 Characteristics of patients with insulinomas

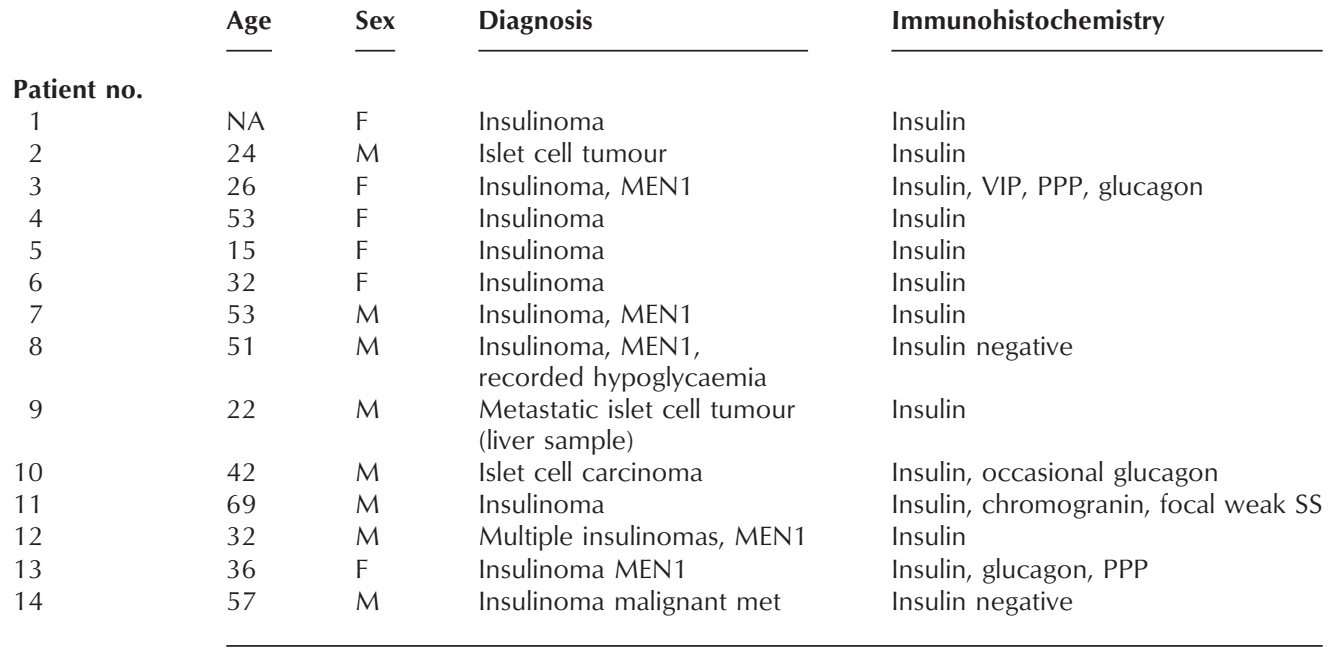

NA, not available; MEN1, multiple endocrine neoplasia type 1; VIP, vasoactive intestinal peptide; PPP, pancreatic polypeptide; SS, somatostatin; met, metastasis.

Table 3 Characteristics of patients with Leydig cell tumours

\begin{tabular}{|c|c|c|c|}
\hline \multirow[b]{2}{*}{ Patient no. } & Age & Sex & Histology \\
\hline & & & \\
\hline 1 & 33 & M & Benign Leydig cell tumour, no invasion \\
\hline 2 & NA & M & Benign Leydig cell tumour, no invasion \\
\hline 3 & 36 & M & Benign Leydig cell tumour, no invasion \\
\hline 4 & 36 & M & Benign Leydig cell tumour, no invasion \\
\hline 5 & 77 & M & Benign Leydig cell tumour, no invasion \\
\hline 6 & 30 & M & Benign Leydig cell tumour, no invasion \\
\hline
\end{tabular}

NA, not available.

(250 ng RNA equivalent), $2 \cdot 5 \mu \mathrm{l}$ Thermophilic DNA Poly $10 \times$ buffer (Promega), 0.25 $\mu \mathrm{l} 20 \mathrm{mM}$ dNTP mix, $0.5 \mu \mathrm{l}$ of each primer at $0.4 \mu \mathrm{M}, 1.5 \mu \mathrm{l} 25 \mathrm{mM} \mathrm{MgCl}_{2}$, and $0 \cdot 125 \mu \mathrm{l}$ Taq DNA polymerase $(5 \mathrm{U} / \mu \mathrm{l})$. For the pituitary samples 35 cycles were performed at $94^{\circ} \mathrm{C}$ for $1 \mathrm{~min}$, $60{ }^{\circ} \mathrm{C}$ for $1 \mathrm{~min}$ and $72{ }^{\circ} \mathrm{C}$ for $1 \mathrm{~min}$, after a first denaturing cycle at $95^{\circ} \mathrm{C}$ for $5 \mathrm{~min}$. A final extension cycle of $10 \mathrm{~min}$ at $72{ }^{\circ} \mathrm{C}$ was used. For gDNA extracted from formalin-fixed, paraffin-embedded tissue, a $25 \mu \mathrm{l}$ PCR reaction was used with $2 \mu \mathrm{l}$ gDNA, $2.5 \mu \mathrm{l} 10 \times$ Qiagen PCR buffer (Qiagen), 0.5 $\mu \mathrm{l} 20 \mathrm{mM}$ dNTP mix, $0 \cdot 5 \mu \mathrm{l}$ of each primer at $0.4 \mu \mathrm{mol} / 1,0.25 \mu \mathrm{l} \mathrm{MgCl}_{2}(25 \mathrm{mM})$, $0 \cdot 25 \mu \mathrm{l}$ Hotstar Taq DNA Polymerase and $5 \mu \mathrm{l}$ Q-Solution. Forty PCR cycles were performed at $94{ }^{\circ} \mathrm{C}$ for $1 \mathrm{~min}, 55^{\circ} \mathrm{C}$ for $1 \mathrm{~min}$ and $72{ }^{\circ} \mathrm{C}$ for $1 \mathrm{~min}$, after a first denaturing cycle at $95^{\circ} \mathrm{C}$ for $15 \mathrm{~min}$. A final extension cycle of $10 \mathrm{~min}$ at $72{ }^{\circ} \mathrm{C}$ was used. To confirm successful amplification the PCR products were run on $2 \%$ ethidium bromide-stained agarose gels and $\Phi X 174$ DNA/Hinfl markers (Promega).

\section{Restriction enzyme reactions and sequencing}

The Leydig cell tumours and 15 of the pituitary adenoma samples were studied using restriction enzyme analysis while a representative group of insulinomas was studied by both sequencing and restriction enzyme analysis. The two single nucleotide substitutions within codon 24 create recognition sites for two restriction endonucleases. The $\operatorname{Arg} \rightarrow$ His mutation (CAT) creates a site for Hsp92II (Promega), while the Arg $\rightarrow$ Cys mutation (TGT) creates a recognition site for StuI (Promega). The PCR primers were designed so that the products would only be cut once by the restriction enzymes in the presence of a mutation. Ten microlitres of the PCR product were digested with $0.5 \mu l$ of the Hsp92II or Stu1 enzyme, $2 \mu$ Restriction Enzyme $10 \times$ buffer K, $0 \cdot 2 \mu \mathrm{l}$ acetylated bovine serum albumin and $7 \cdot 3 \mu \mathrm{l}$ water to bring the total volume to $20 \mu \mathrm{l}$. The reactions were mixed gently by pipetting and incubated at $37^{\circ} \mathrm{C}$ for $2 \mathrm{~h}$ and $65^{\circ} \mathrm{C}$ for $25 \mathrm{~min}$ at the end of the digestion period. Ten microlitres of the digest were then used to run on a $4.5 \%$ metasieve agarose gel (Flowgen, Ashby, Leicestershire, UK) together with uncut PCR samples. Direct sequencing was performed on all the pituitary cDNA samples and all the insulinomas using the ABI Prism 3700 DNA Analyzer - for details see Kola et al. (2003).

\section{Immunohistochemistry}

The sections were mounted on positively-charged microscope slides (Superfrost Plus; Fisher Scientific, Fair Lawn, NJ, USA) and baked at $60{ }^{\circ} \mathrm{C}$ for $2 \mathrm{~h}$. The slides were routinely dewaxed and rehydrated. The endogenous 


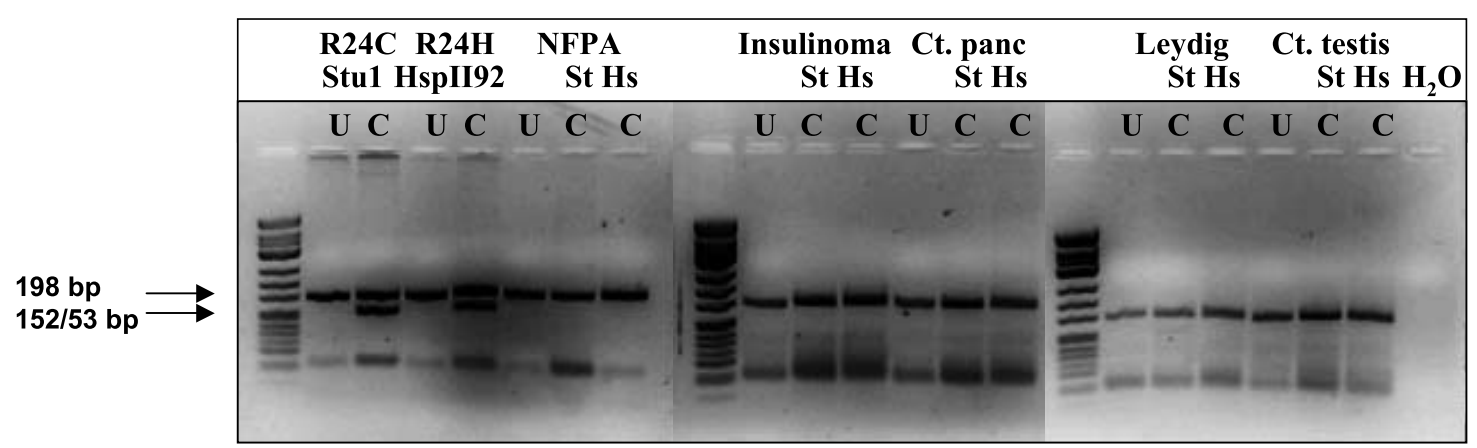

Figure 2 Representative $4.5 \%$ agarose gel of non-functioning pituitary adenoma (NFPA), insulinoma and control pancreas (ct. panc) and Leydig cell tumour and control testis (ct. testis) samples amplified with the gDNA primers and cut with the Stul (St) and HSPII92 (Hs) restriction enzymes. U, uncut PCR product; C, cut with restriction enzymes.

peroxidase activity was then quenched with $0.5 \% \mathrm{H}_{2} \mathrm{O}_{2}$ in methanol for $10 \mathrm{~min}$. A microwave antigen retrieval method (20 min in $10 \mathrm{mM}$ citrate buffer, $\mathrm{pH} 6 \cdot 0$, at 600 watts) was used, followed by incubation with polyclonal horse serum (20 min, 1:100 dilution: Dako, Glostrup, Denmark) and with rabbit polyclonal anti-CDK4 antibody (clone sc-260, overnight, $4{ }^{\circ} \mathrm{C}$ ), at $2 \mu \mathrm{g} / \mathrm{ml}$ (Santa Cruz Biotechnology, Inc., Santa Cruz, CA, USA). Then sections were serially incubated with biotinylated antimouse antibody (30 min, 1:200 dilution; Dako), and peroxidaselabelled avidin-biotin complex (60 min, 1:100 dilution; Dako). All incubations were performed in a moist chamber at room temperature. The reaction was developed under microscopic control, using 3,3'diaminobenzidine tetrahydrochloride with $0 \cdot 3 \% \mathrm{H}_{2} \mathrm{O}_{2}$ as chromogen (Sigma Chemical Co., St Louis, MO, USA), and the sections were counterstained with haematoxylin. Both positive (reactive lymph node) and negative (omitting the primary antibody) controls were simultaneously run. The specificity of the reaction was tested using blocking peptide in competition studies (sc-260-P, Santa Cruz Biotechnology, Inc.).

\section{Western blotting}

Pituitary tissue samples were homogenised in Cytobuster protein extraction reagent (Novagen, CN Biosciences, Nottingham, Notts, UK). The protein concentration of the lysates was normalized using the Bradford assay (Bio-Rad, Hemel Hempstead, Middlesex, UK). Samples $(10 \mu \mathrm{g})$ were subjected to $10 \%$ SDS-PAGE separation, with protein transfer to PVDF nitrocellulose membrane. The membrane was blocked with $5 \%$ non-fat milk for $90 \mathrm{~min}$ and incubated overnight at $4{ }^{\circ} \mathrm{C}$ using rabbit polyclonal anti-CDK4 antibody (1:1000, clone sc-260, Santa Cruz Biotechnology, Inc.) as the primary antibody. The membrane was washed 3 times with PBS containing $0.05 \%$ Tween and subsequently incubated with horseradish peroxidase (HRP)-conjugated anti-rabbit antibody as the secondary antibody $(1: 10000$, Dako) for $2 \mathrm{~h}$ at room temperature. A chemiluminescent peroxidase substrate, ECL Plus (Amersham-Pharmacia, Amersham, Bucks, UK), was applied according to the manufacturer's instructions, and the membranes were exposed briefly to X-ray film. Equal protein loading was determined by stripping the PVDF membrane with Tris hydrochloride, SDS and 2-mercaptoethanol, and re-probing for $\beta$ actin (1:5000, ab6276, Abcam, Cambridge, Cambs, UK).

\section{Results}

The area of CDK4 gene containing codon 24 was successfully amplified in all the samples using the gDNA or the cDNA primers. The positive control samples showed the expected heterozygote pattern by both restriction enzyme analysis (Fig. 2) and sequencing (Fig. 3). No abnormal restriction enzyme patterns or sequencing results were detected at the area including codon 24 of the CDK4 gene in any of the 61 pituitary adenomas, the 14 insulinoma samples or in the 6 Leydig cell tumours (Figs 2 and 3). CDK protein expression was detected in insulinomas with immunohistochemistry, where the specificity of the staining was shown by blocking the staining with the antigen (Fig. 4). Western blotting on normal pituitary and pituitary adenomas showed variable expression of the expected $34 \mathrm{kDa}$ size protein, with no consistent difference from normal tissue (Fig. 5).

\section{Discussion}

We have studied the possible involvement of 2 different activating point mutations in the cell cycle regulator CDK4 in sporadic human endocrine tumours, based on findings in the corresponding transgenic mouse model which develops insulinomas, Leydig cell tumours and pituitary adenomas when such mutations are present (Sotillo et al. 2001). No mutations were found in any of these neoplasms at codon R24, or in the surrounding area 


\section{Normal sequence from a pituitary adenoma}

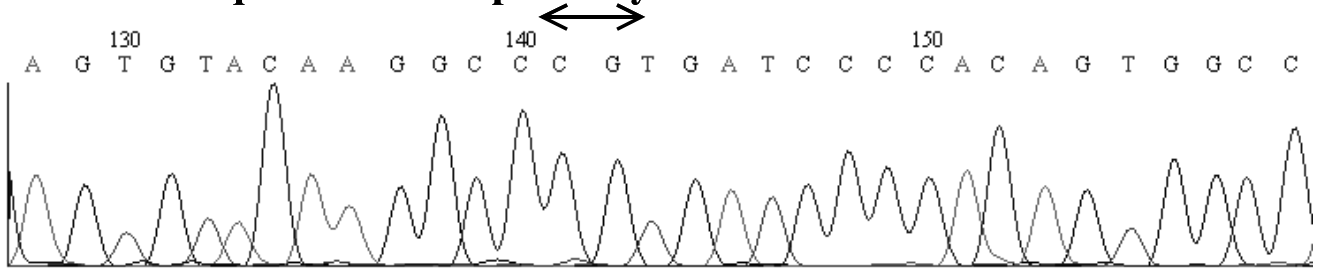

\section{Heterozygote R24C mutation (CGT $\rightarrow$ TGT)}

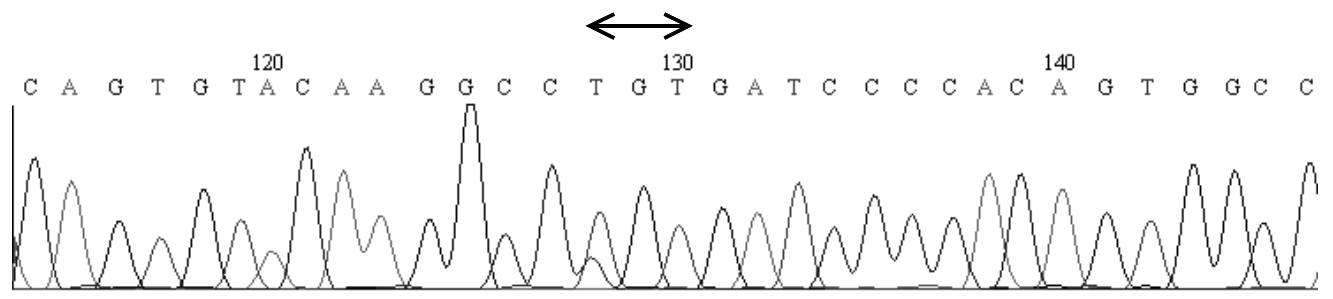

\section{Heterozygote R24H mutation $(\mathrm{CGT} \rightarrow \mathrm{CAT})$}

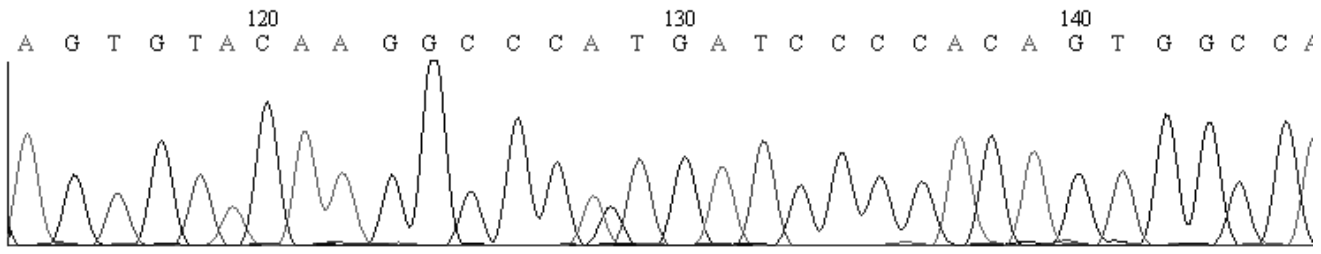

Figure 3 Sequencing traces from a pituitary adenoma (no mutation) and the two positive control samples (heterozygote R24C and R24H mutation).

from codon 1 to codon 41. However, CDK4's role cannot be totally ruled out as several non-contiguous amino-acid sequences on CDK4 are required for binding to p16 (codons 22, 24, 25, 97 and 281) (Ceha et al. 1998) and only codons 22, 24 and 25 were investigated by sequencing in our study, although no germline or sporadic CDK4 mutations outside codons 22-24 have been reported to date. We were able to detect CDK4 protein in both the insulinoma and pituitary samples using immunohistochemistry and immunoblotting, and significantly altered expression of CDK4 protein could not be detected.

Loss of regulation of the G1 checkpoint appears to be an extremely common event among virtually all types of tumours. A number of genetic and epigenetic mechanisms have been shown to be responsible for this process. The two types of proteins that are of central importance are the cyclins and cyclin-dependent kinases. CDK4 and CDK6, which associate with the D-type cyclins, are expressed in most tissues but the abundance of the two proteins may be cell specific. Over-expression of cyclin D1, due to amplification of the cyclin D1 gene, has been reported in many tissues and cell lines including the breast, oesophagus and colorectal tissue. It was therefore reasonable to speculate that its regulatory counterpart, CDK4, could harbour genetic alterations that may lead to tumorigenesis.

Considering that CDK4 is a potential oncogene, mechanisms of activation could include gene amplification, over-expression and decreased degradation, other than activating mutations. In humans, point mutations in the CDK4 gene have been described in familial melanoma. The CDK4 gene is amplified and overexpressed in a number of human tumours including the gliomas, sarcomas, breast tumours and colorectal carcinomas: 6 of 67 osteosarcoma samples demonstrated CDK4 gene amplification using quantitative Southern blot analysis (Wei et al. 1999). In colorectal carcinomas immunohistochemical analysis using antibodies to CDK4 revealed a positive correlation between elevated levels of CDK4 and enhanced dysplasia of the adenomas (Bartkova et al. 2001). This study again supported the notion that defects in CDK4 could lead to disruption of cell cycle control. Further support for the proliferative properties of CDK4 comes from transgenic mice over-expressing the CDK4 gene under a keratin 5 promoter (Miliani de Marval et al. 2001). 


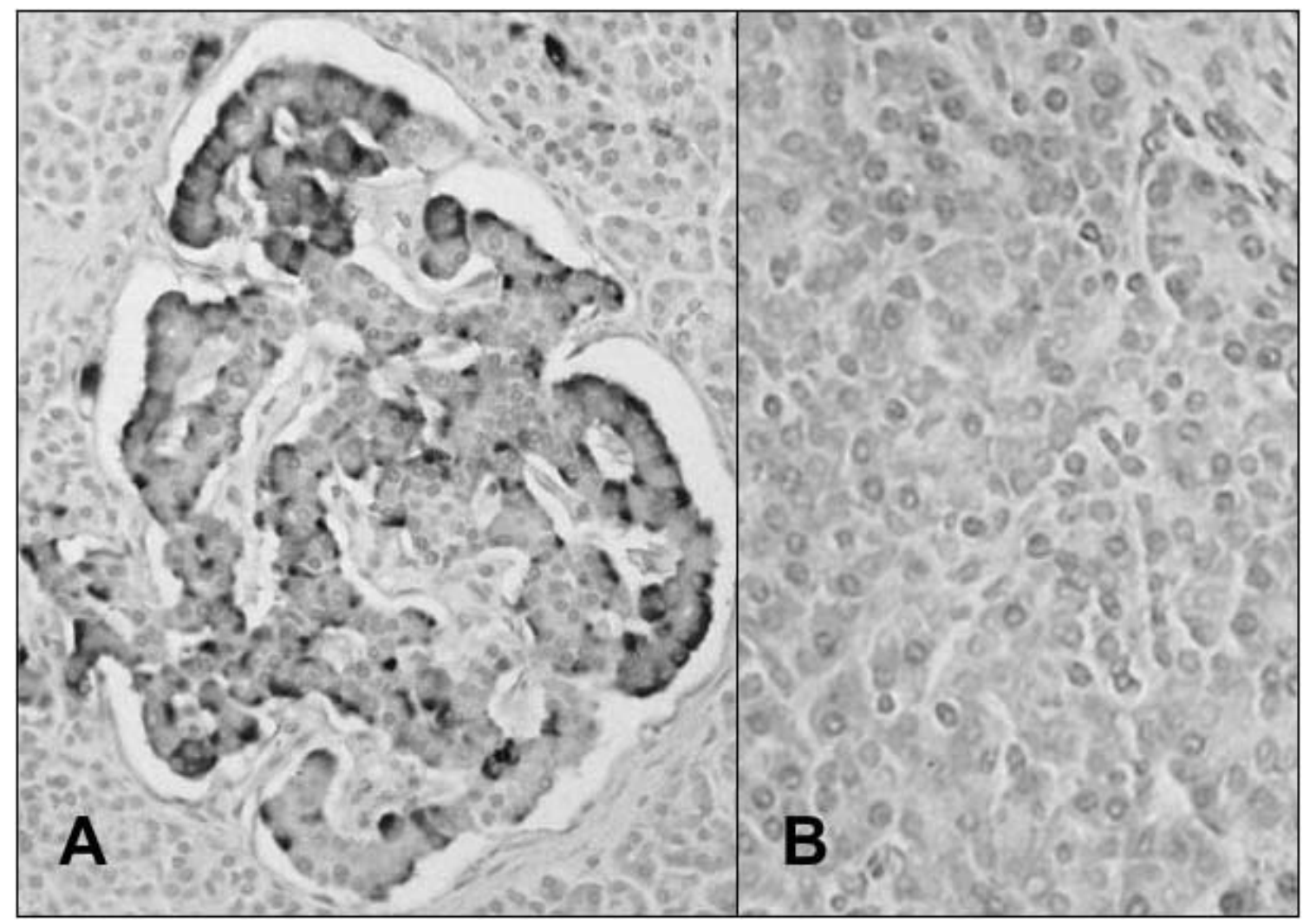

Figure 4 (A) Variable immunoexpression of CDK4 is present in a pancreatic insulinoma (magnification $200 \times$ ).

(B) Pretreatment with blocking peptide inhibits the positive staining (magnification $200 \times$ ).
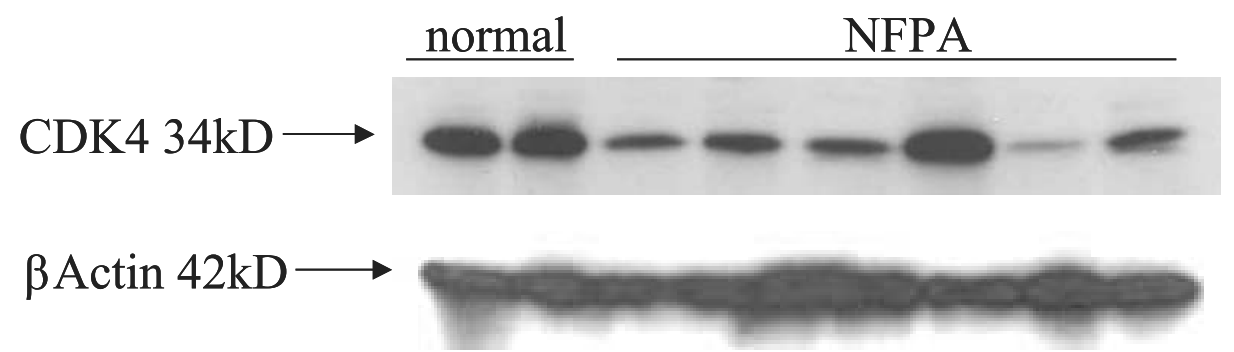

Figure 5 Immunoblotting with CDK4 antibody (upper gel) and $\beta$ actin (lower gel) in normal (autopsy) pituitaries and non-functioning pituitary adenomas (NFPA).

The mice developed severe dermal fibrosis, epidermal hyperplasia and hypertrophy, independent of D-type cyclin expression. Furthermore, expression of CDK4 has been shown to have prognostic value: cyclin D1 and CDK4 are possible candidates for prognostic markers in laryngeal squamous cell carcinomas (Dong et al. 2001). Over-expression of CDK4 was observed in 47\% (48/102) of laryngeal tumours and was significantly associated with overall poor survival. Both cyclin D1 and CDK4 over-expression were independent prognostic factors, but the poorest outcome was associated with cooverexpression of both cyclin D1 and CDK4. Pituitary adenomas have been studied for abnormalities in the p16 pathway, including CDK4 for the Arg $\rightarrow$ Cys mutations at codon 24, but no mutation was found (Simpson et al. 2001). The latter study examined 45 human pituitary tumours and looked at several components of the cell cycle i.e. Rb, p16, cyclin D1 and CDK4, to assess their overall contribution to pituitary tumorigenesis. Whilst a significant percentage of the tumours had abnormal expression of $\mathrm{Rb}$, p16 and cyclin D1 proteins, not a single pituitary sample showed the CDK4 R24C mutation. Ten of the samples were randomly selected to undergo sequencing of the codon 24 region, but no mutations were detected. 
However, the majority of the samples were not tested for the $\mathrm{Arg} \rightarrow$ His mutation. In a recent paper it has been suggested that in $\mathrm{CDK} 4^{\mathrm{R} 24 \mathrm{C} / \mathrm{R} 24 \mathrm{C}}$ transgenic mice the activating mutation does not just facilitate tumorigenesis but also aids escape from cellular senescence and contactinduced growth arrest (Rane et al. 2002).

While p16 changes are common in melanoma families, CDK4 changes are rare (Goldstein et al. 2002). A 13-fold increase in the incidence of pancreatic (exocrine) cancer in melanoma-prone kindreds with p16 mutations has been described (Goldstein et al. 1995), and the risk of breast cancer is also increased (Borg et al. 2000). No report has been published on endocrine abnormalities in these families harbouring p16 or CDK4 abnormalities. Interestingly, a recent preliminary report describes a patient with deletion of chromosome $9 p$ (encompassing the $p 16-$ CDKN2A locus): this patient at the age of 16 developed a number of melanomas and dysplastic naevi as well as a gonadotrophin-secreting pituitary tumour (Kumar et al. 2002).

In conclusion, the importance of the CDK4/p16 pathway has been established in a range of different tumour types, suggesting that the development of cyclindependent kinase inhibitor drugs could lead to useful anti-neoplastic agents (Sausville 2002). CDK4 R24C plays a major role in mouse endocrine tumorigenesis, but in the current study we could not detect any CDK4 abnormalities in sporadic endocrine human tumours. This suggests that CDK4 may play a different role in the human as compared with mouse endocrine cells.

\section{Acknowledgements}

V V V was supported by the Royal Society, M G was supported by the Joint Research Board of St Bartholomew's Hospital, MK was supported by the MRC, and the project was supported by a grant from the Cancer Research Committee of St Bartholomew's Hospital. We are grateful to the referring clinicians Professor $\mathrm{J} \mathrm{P}$ Monson, Dr S L Chew \& Dr P J Jenkins for allowing us access to their patients.

\section{References}

Bartkova J, Thullberg M, Slezak P, Jaramillo E, Rubio C, Thomassen LH \& Bartek J 2001 Aberrant expression of G1-phase cell cycle regulators in flat and exophytic adenomas of the human colon. Gastroenterology 120 1680-1688.

Borg A, Sandberg T, Nilsson K, Johannsson O, Klinker M, Masback A, Westerdahl J, Olsson H \& Ingvar C 2000 High frequency of multiple melanomas and breast and pancreas carcinomas in CDKN2A mutation-positive melanoma families. Journal of the National Cancer Institute 92 1260-1266.

Ceha HM, Nasser I, Medema RH \& Slebos RJ 1998 Several noncontiguous domains of CDK4 are involved in binding to the P16 tumor suppressor protein. Biochemical and Biophysical Research Communications 249 550-555.
Diaz-Cano SJ \& Brady SP 1997 DNA extraction from formalin-fixed, paraffin-embedded tissues: protein digestion as a limiting step for retrieval of high-quality DNA Diagnostic Molecular Pathology 6 342-346.

Dong Y, Sui L, Sugimoto K, Tai Y \& Tokuda M 2001 Cyclin D1-CDK4 complex, a possible critical factor for cell proliferation and prognosis in laryngeal squamous cell carcinomas. International Journal of Cancer 95 209-215.

Goldstein AM, Fraser MC, Struewing JP, Hussussian CJ, Ranade K, Zametkin DP, Fontaine LS, Organic SM, Dracopoli NC \& Clark WH Jr 1995 Increased risk of pancreatic cancer in melanoma-prone kindreds with p16 INK4 mutations. New England Journal of Medicine 333 970-974.

Goldstein AM, Chidambaram A, Halpern A, Holly EA, Guerry ID, Sagebiel R, Elder DE \& Tucker MA 2002 Rarity of CDK4 germline mutations in familial melanoma. Melanoma Research 12 $51-55$.

Kefford R, Bishop JN, Tucker M, Bressac-de Paillerets B, Bianchi-Scarra G, Bergman W, Goldstein A, Puig S, Mackie R, Elder D, Hansson J, Hayward N, Hogg D \& Olsson H 2002 Genetic testing for melanoma. Lancet Oncology 3 653-654.

Kola B, Korbonits M, Kaltsas GA, Morris DG, Metherell L, Powell MP, Czirják S, Arnaldi G, Bustin SA, Boscaro M, Mantero F \& Grossman AB 2003 Growth hormone receptor and type 1 insulinlike growth factor receptor expression in human somatotroph tumors. Clinical Endocrinology (In Press).

Korbonits M, Chitnis MM, Gueorguiev M, Norman D, Rosenfelder N, Suliman M, Jones TH, Noonan K, Fabbri A, Besser GM, Burrin JM \& Grossman AB 2001 The release of leptin and its effect on hormone release from human pituitary adenomas. Clinical Endocrinology 54 781-789.

Kumar S, Lindor NM, Smithson WA \& Lteif AN 2002 Concurrent melanoma and pituitary adenoma associated with deletion of CDKN2A. Proceedings of the 84rd Annual Meeting of the Endocrine Society, San Francisco CA USA. P3-564 (Abstract).

Malumbres M \& Barbacid M 2001 To cycle or not to cycle: a critical decision in cancer. Nature Review Cancer 1 222-231.

Miliani de Marval PL, Gimenez-Conti IB, LaCava M, Martinez LA, Conti CJ \& Rodriguez-Puebla ML 2001 Transgenic expression of cyclin-dependent kinase 4 results in epidermal hyperplasia, hypertrophy, and severe dermal fibrosis. American Journal of Pathology 159 369-379.

Pavletich NP 1999 Mechanisms of cyclin-dependent kinase regulation: structures of Cdks, their cyclin activators, and Cip and INK4 inhibitors. Journal of Molecular Biology 287 821-828.

Rane SG, Dubus P, Mettus RV, Galbreath EJ, Boden G, Reddy EP \& Barbacid M 1999 Loss of Cdk4 expression causes insulindeficient diabetes and Cdk4 activation results in beta-islet cell hyperplasia. Nature Genetics 22 44-52.

Rane SG, Cosenza SC, Mettus RV \& Reddy EP 2002 Germ line transmission of the Cdk4(R24C) mutation facilitates tumorigenesis and escape from cellular senescence. Molecular and Cellular Biology 22 644-656.

Sausville EA 2002 Complexities in the development of cyclindependent kinase inhibitor drugs. Trends in Molecular Medicine $\mathbf{8}$ S32-S37.

Simpson DJ, Frost SJ, Bicknell JE, Broome JC, McNicol AM, Clayton RN \& Farrell WE 2001 Aberrant expression of G(1)/S regulators is a frequent event in sporadic pituitary adenomas. Carcinogenesis 22 1149-1154.

Sotillo R, Dubus P, Martin J, de la Cueva E, Ortega S, Malumbres M \& Barbacid M 2001 Wide spectrum of tumors in knock-in mice carrying a $\mathrm{Cdk} 4$ protein insensitive to INK 4 inhibitors. EMBO Journal 20 6637-6647.

Soufir N, Avril MF, Chompret A, Demenais F, Bombled J, Spatz A, Stoppa-Lyonnet D, Benard J \& Bressac-de Paillerets B 1998 
Prevalence of $\mathrm{p} 16$ and CDK4 germline mutations in 48 melanoma-prone families in France. The French Familial Melanoma Study Group. Human Molecular Genetics 7 209-216.

Wei G, Lonardo F, Ueda T, Kim T, Huvos AG, Healey JH \& Ladanyi M 1999 CDK4 gene amplification in osteosarcoma: reciprocal relationship with INK4A gene alterations and mapping of 12q13 amplicons. International Journal of Cancer 80 199-204.

Wölfel T, Hauer M, Schneider J, Serrano M, Wölfel C, Klehmann-Hieb E, De Plaen E, Hankel T, Meyer zum Buschenfelde KH \& Beach D 1995 A p16 INK4a-insensitive CDK4 mutant targeted by cytolytic T lymphocytes in a human melanoma. Science 269 1281-1284.
Zhang HS, Postigo AA \& Dean DC 1999 Active transcriptional repression by the $\mathrm{Rb}-\mathrm{E} 2 \mathrm{~F}$ complex mediates $\mathrm{G} 1$ arrest triggered by p16 INK4a, TGFbeta, and contact inhibition. Cell 97 53-61.

Zuo L, Weger J, Yang Q, Goldstein AM, Tucker MA, Walker GJ, Hayward N \& Dracopoli NC 1996 Germline mutations in the p16 INK4a binding domain of CDK4 in familial melanoma. Nature Genetics 12 97-99.

Received in final form 2 May 2003

Accepted 14 May 2003 